\begin{tabular}{lll}
\hline institute & $\begin{array}{c}\text { CARADDE: Jurnal Pengabdian Kepada Masyarakat } \\
\text { https://journal.ilininstitute.com/index.php/caradde } \\
\text { Volume 1 | Nomor 2 | Februari | } 2019 \\
\text { e-ISSN: 2621-7910 dan p-ISSN: 2621-7961 }\end{array}$ & $\begin{array}{l}\text { Iin } \\
\text { DOI: https://doi.org/10.31960/caradde.v1i2.69 }\end{array}$ \\
\hline
\end{tabular}

\title{
Pemberdayaan Masyarakat Marannu melalui Pertanian dan Peternakan Terintegrasi dalam Rangka Mewujudkan Kabupaten Pinrang Sebagai Poros Utama Pemenuhan Pangan Nasional
}

\author{
Muhammad Rusli Baharuddin ${ }^{1}$, Gita Sri Hidayati ${ }^{2}$, Baso Amir ${ }^{3}$
}

\begin{tabular}{ll}
\hline \hline Keywords: & Abstrak. Tujuan kegiatan ini yaitu Penumbuhkan empati, jiwa \\
Kuliah Kerja Nyata; & kepemimpinan, kewirausahaan, kerja sama mahasiswa, dan \\
Pertanian dan Peternakan & $\begin{array}{l}\text { dapat memberikan sumbangan bagi penyelesaian persoalan yang } \\
\text { ada di masyarakat. Secara Khusus kegiatan ini bertujuan untuk }\end{array}$ \\
Teringterasi; & meningkatkan kualitas dan kuantitas produksi pertanian dan \\
& peternakan dengan menghasilkan pakan ternak dari pengolahan \\
Corespondensi Author & limbah pertanian dan pupuk organik dari pengolahan limbah \\
Matematika Terapan, & peternakan. Metode Pelaksanaan yang diterapkan untuk \\
Universitas Cokroaminoto & mencapai tujuan yaitu (1) Sosialisasi Pertanian: Penggunaan \\
Palopo, Jl. Latamacelling No. & pupuk organik dan bahaya penggunaan pupuk kimia, (2) \\
19 B Palopo & Sosialisasi Peternakan: Pemenuhan gisi dan pemberian vaksin \\
Email: mruslib@gmail.com & ternak, (3) Pengolahan limbah pertanian menjadi pakan ternak, \\
gita.flozia@gmail.com & (4) Pengolahan limbah peternakan menjadi pupuk organik, dan \\
bas amt@yahoo.com & (5) Pemberdayaan masyarakat pengangguran dalam pengolahan \\
& pupuk organik dan pakan ternak, Hasil (Luaran) dalam kegiatan \\
History Artikel & ini adalah (1) Meningkatkannya hasil panen pertanian dari \\
Received: Agustus-2018; & jumlah hasil panen sebelumnya, (2) Terjadinya penurunan biaya \\
Reviewed: Oktober-2018; & produksi atau pembelian pakan ternak dari periode sebelumnya \\
Accepted: November-2018; & dan (3) 50\% petani Desa marannu menggunakan pupuk organik \\
Published: Februari-2019; & hasil pengolahan Limbah dan Peternakan 50\% Peternak Desa \\
& Marannu menggunakan pakan ternak hasil pengolahan limbah \\
& pertanian. Konsep pertanian dan peternakan terintegrasi sebagai \\
& langkah Kabupaten Pinrang Sebagai Poros Utama Pemenuhan
\end{tabular}

(1) This work is licensed under a Creative Commons Attribution

4.0 International License

\section{PENDAHULUAN}

Kabupaten Pinrang memiliki garis pantai sepanjang $93 \mathrm{Km}$ sehingga terdapat areal pertambakan sepanjang pantai, pada dataran rendah didominasi oleh areal persawahan, bahkan sampai perbukitan dan pegunungan. Kondisi ini mendukung Kabupaten Pinrang sebagai daerah Potensial untuk pertanian dan memungkinkan berbagai komoditi pertanian (Tanaman Pangan, perikanan, perkebunan dan Peternakan) untuk dikembangkan. Direktorat Jenderal Peternakan (2010). Bahkan pemerintah kabupaten pinrang menjadikan pertanian sebagai potensi unggulan dan menjadi prioritas untuk dikembangkan dengan slogan "We Strong In Agriculture".

Berdasarkan data Badan Pusat Statistik (2016) Kabupaten dengan Jumlah penduduk sebesar \pm 335.270 jiwa yang terdiri atas 160.647 jiwa laki-laki dan 174.623 jiwa perempuan dengan tingkat kepadatan 
penduduk mencapai $171 \mathrm{jiwa} / \mathrm{km}^{2}$ ini. Sehingga sangat potensial dalam pertanian, perkebunan dan pertanakan dengan harapan terwujudnya misi kabupaten pinrang yaitu menjadi poros utama pemenuhan pangan nasional. Salah satu cara yang ditempuh pemerintah kab. Pinrang adalah rekayasa teknologi bibit unggul atau sering yang kenal dengan istilah 'revolusi hijau' (Green Revolution).

Menurut Das (2013) Implementasi Revolusi hijau dengan menggunakan pupuk kimia buatan pabrik, penanaman varietas unggul berproduksi tinggi (high yield variety), penggunaan pestisida, intensifikasi lahan dan lain-lain mengalami peningkatan. Sejalan dengan itu, Hamdaka (2009) Pada awalnya revolusi hijau di Indonesia memberikan hasil yang signifikan terhadap pemenuhan kebutuhan pangan nasional yaitu peningkatan produksi padi sebesar $3,63 \%$ dari produksi sebelumnya;

Belakangan ditemukan berbagai permasalahan akibat kesalahan manajemen di lahan pertanian. Pencemaran pupuk kimia buatan pabrik, pestisida dan bahan buatan pabrik lainnya akibat kelebihan pemakaian, berdampak terhadap penurunan jumlah produksi pertanian, kualitas lingkungan dan kesehatan manusia. Pemahaman akan bahaya bahan kimia buatan pabrik dalam jangka waktu lama mulai disadari sehingga perlu cara bercocok tanam yang dapat menghasilkan produk yang bebas dari cemaran bahan kimia buatan pabrik dan meningkatkan hasil panen serta menjaga lingkungan yang lebih sehat. Sejak itulah mulai dilirik kembali cara pertanian alamiah (back to nature).

Di sisi lain, bidang Peternakan kabupaten pinrang juga mengalami permasalahan terhadap penyediaan pakan ternak. Muncul permasalahan ini diakibatkan penyempitan lahan pengembalaan, persaingan bahan baku pakan untuk kebutuhan lain, kandungan nutrisi yang rendah, teknologi pengolahan terbatas, dan distribusi masih terbatas. Selain itu, untuk pemenuhan pakan, peternak harus mengeluarkan biaya lebih untuk menutupi kebutuhan pakan. Padahal, banyak limbah pertanian yang belum termanfaatkan secara maksimal.
Secara garis besar ada dua permasalahan pokok yang harus diselesaikan yaitu manajemen pertanian untuk meningkatkan produksi pertanian dan ketersedian pakan ternak. Sebagai langkah penyelesaian permasalahan maka diperlukan pemberdayaan masyarakat melalui pertanian dan peternakan terintegrasi yaitu limbah pertanian akan dimanfaatkan sebagai pakan ternak dan limbah ternak akan diolah menjadi pupuk organik dan dimanfaatkan untuk kebutuhan pertanian.

Sosialisasi Pertanian: penggunaan pupuk organik dan bahaya penggunaan pupuk kimia, Sosialisasi Peternakan: pemenuhan gisi ternak dan pemberian vaksin ternak, Pengolahan limbah pertanian menjadi pakan ternak dengan memanfaatkan teknologi pencacah limbah, Pengolahan limbah peternakan menjadi pupuk organik dengan memanfaatkan teknologi pencacah bahan baku pupuk, Pemberdayaan masyarakat pengangguran dalam pengolahan pupuk organik dan pakan ternak.

Target yang diharapkan pada kegiatan KKN-PPM Pemberdayaan Masyarakat Marannu melalui Pertanian dan Peternakan Terintegrasi adalah Mewujudkan Kabupaten Pinrang Sebagai Poros Utama Pemenuhan Pangan Nasional. Pemenuhan pangan nasional bias terwujud jika terjadi peningkatan hasil panen pertanian, peningkatan kualitas dan kuantitas peternakan, efesiensi biaya produksi (Ketersediaan Pakan ternak dan pupuk Organik) dan peningkatan partisipasi masyarakat pengangguran dengan usia produktif. Secara rinci target luaran dan indikator capaian Program KKN-PPM sebagai berikut: (a) Meningkatkannya hasil panen pertanian dari jumlah hasil panen sebelumnya; (b) Terjadinya penurunan biaya produksi atau pembelian pakan ternak dari periode sebelumnya; (c) $50 \%$ petani Desa marannu menggunakan pupuk organik hasil pengolahan Limbah Peternakan; (d) Bersamasama mengelola Limbah pertanian dan peternakan menjadi pupuk organik dan pakan ternak

\section{METODE}

Program yang diusulkan dalam KKNPPM merupakan program-program yang 
sangat dibutuhkan oleh warga desa Marannu, sehingga untuk memaksimalkan pelaksanaannya, perlu dilakukan kegiatankegiatan persiapan dan pembekalan kepada mahasiswa yang nantinya akan ditugaskan di daerah tersebut.

Pembekalan mahasiswa KKN-PPM bertujuan untuk memberikan pengetahuan dan pemahaman tentang pelaksanaan KKNPPM. Materi pembekalan KKN-PPM meliputi visi, misi, tujuan Kuliah Kerja Nyata UNCP, sikap dan perilaku mahasiswa KKNPPM di masyarakat, Penggunaan pupuk organik dan bahaya penggunaan pupuk kimia, pemenuhan gisi ternak dan pemberian vaksin ternak, Pengolahan limbah pertanian dan peternakan, Pemberdayaan masyarakat pengangguran dan pemanfaatan teknologi tepat guna dalam pengolahan limbah, serta teknis pelaksanaan KKN-PPM.

Kegiatan pembekalan mahasiswa dilaksanakan paling lambat satu minggu sebelum pemberangkatan KKN-PPM. Untuk mengetahui keberhasilan pembekalan mahasiswa, maka dilakukan evaluasi pelaksanaan pembekalan. Lembar evaluasi tersebut meliputi kesesuaian materi pembekalan, kritik dan saran untuk pelaksanaan pembekalan KKN.

Program kerja KKN-PPM yang telah disusun akan dilaksanakan berdasarkan Bentuk Program, Metode dan Langkah Operasional yang dipapakan di bawah: (1) Operasional Pelaksanaan Sosialisasi Program pertanian dan peternakan terintegrasi yaitu Sosialisasi mekanisme program KKN-PPM, Perkenalan mahasiswa KKN-PPM, Pemaparan program kerja KKN-PPM 2018, dan Peninjauan lokasi pertanian dan peternakan; (2) Operasional Pelaksanaan Pelatihan pembuatan pupuk organik yaitu Pengumpulan Limbah Ternak, Persiapan Pelatihan pembuatan pupuk organik, Manfaat pupuk organik dan bahaya penggunaan pupuk kimia dan Demonstrasi pembuatan pupuk organic; 3) Operasional Pelaksanaan Pelatihan pembuatan pakan ternak yaitu Pengumpulan Limbah Pertanian, Persiapan Pelatihan pembuatan pakan ternak, Pemenuhan gisi ternak dan pemberian vaksin ternak, Demonstrasi pembuatan pakan ternak; (4) Operasional Implementasi Program pertanian dan peternakan terintegrasi yaitu Persiapan Alat dan bahan yang akan digunakan, Pengolahan Limbah
Pertanian menjadi Pakan ternak, Pengolahan Limbah Ternak menjadi Pupuk Organik, Pengujian Pupuk Organik; (5) Operasional Pelaksanaan Monitoring dan evaluasi yaitu Identifikasi kendala yang dihadapi, Refleksi hasil evaluasi, dan Rekomendasi ke pemerintah Setempat; (6) Operasional Pelaksanaan Keberlanjutan Program yaitu Laporan Program Pertanian dan Peternakan Terintegrasi, Pengalihan Pengelolaan Program Ke Masyarakat dan Penarikan Mahasiswa KKN-PPM

\section{HASIL DAN PEMBAHASAN}

Kegiatan integrasi yang dilaksanakan juga berorientasi pada usaha pertanian dan peternakan tanpa limbah (zero waste). Menurut Murbandono (2008) kegiatan mengintegrasikan usaha budidaya tanaman dan ternak merupakan solusi permasalahan limbah, dimana limbah tanaman diolah untuk pakan ternak dan limbah ternak (faeces, urine) diolah menjadi pupuk organik dan bio pestisida.

Petani kebun akan menyediakan peternak berupa limbah perkebunan dari pertengahan musim hujan hingga awal musim kemarau berupa Limbah Kacang tanah, Jagung dan lain sebagainya untuk ditukar dengan Pupuk Organik. Sedangkan petani sawah akan menyediakan peternak berupa limbah pertaniannya berupa jerami padi, jerami kedele dan jerami palawija disetiap musim panen tiba untuk ditukar dengan pupuk organik.

Peternak akan menyediakan limbah ternak seperti kotoran sapi, ayam, kerbau dan lain-lainnya untuk di olah menjadi pupuk organik. Sehingga akan tercapai pola pertanian, perkebunan dan peternakan terintegrasi yang berkesinambungan dan melembaga, kuat dan tercapainya yang secara berkelanjutan.

Model pertanian dan peternakan terintegrasi melalui program KKN-PPM di Kabupaten Pinrang berorientasi pada konsep produksi tanpa limbah (zero waste production system), yaitu seluruh limbah dari ternak dan tanaman didaur ulang dan dimanfaatkan kembali ke dalam siklus produksi. Komponen usaha tani dalam model ini meliputi usaha ternak sapi, ayam, tanaman pangan (padi atau jagung) dan hortikultura (sayuran). 
Limbah ternak (kotoran sapi) diproses menjadi kompos dan pupuk organik sedangkan limbah pertanian (jerami padi, batang dan daun jagung, pucuk tebu, jerami kedelai dan kacang tanah) diproses menjadi pakan ternak (Direktorat Jenderal Peternakan, 2010).

Dukungan teknologi dalam kegiatan KKN-PPM pertanian peternakan terintegasi sangat diperlukan terutama dalam proses pengolahan limbah ternak menjadi pupuk organik dan limbah pertanian menjadi pakan ternak. Teknologi yang akan diterapkan KKN-PPM ini adalah alat pencacah limbah pertanian dan peternakan. Limbah yang akan di olah menjadi pupuk organik dan pakan ternak terlebih dahulu di cacah agar proses pengolahan menjadi lebih cepat dan efesien.

Model pertanian dan peternakan terintegrasi dalam KKN-PPM di kab pinrang dijadikan sebagai solusi dengan pertimbangan bahwa keberlanjutan pemberdayaan masyarakat, setelah kegiatan KKN-PPM maka model terintegrasi tetap berjalan karena dikelola langsung oleh masyarakat setempat sehingga dapat meningkatkan jumlah produksi hasil pertanian dan peternakan, mengurangi biaya operasional kegiatan pertanian dan peternakan

Ada tiga kelompok sasaran pada kegiatan KKN-PPM di kabupaten pinrang yaitu kelompok masyarakat petani, kelompok masyarakat peternak, dan masyarakat umum.

Kelompok Petani: Kelompok petani yang menjadi sasaran kegiatan KKN-PPM ini adalah petani padi. Jagung, kedelai, dan sayuran. Sistem pertanian yang selama ini diterapkan adalah melalui penggunaan pupuk kimia sehingga menambah biaya untuk pembelian pupuk (Operasional pertanian). Akibatnya, Produktivitas hasil panen semakin berkurang akibat penggunaan pupuk kimia secara berlebihan.

Kelompok Peternak: Kelompok peternak yang menjadi sasaran kegiatan KKN-PPM adalah peternak sapi /ayam. permasalahan yang dialami kelompok peternak adalah penyediaan pakan ternak. Muncul permasalahan ini diakibatkan penyempitan lahan pengembalaan, persaingan bahan baku pakan untuk kebutuhan lain, kandungan nutrisi yang rendah, teknologi pengolahan terbatas, industri dan sistem distribusi masih terbatas. Selain itu, untuk pemenuhan pakan, peternak harus mengeluarkan biaya lebih (operasional Peternakan). Padahal, banyak limbah pertanian yang belum termanfaatkan secara maksimal.

Masyarakat Umum/Pengangguran: Masyarakat Umum yang menjadi sasaran kegiatan KKN-PPM adalah masyarakat yang tidak memiliki pekerjaan dan putus sekolah. Permasalahan yang dihadapi masyarakat adalah tidak adanya pendapatan, akibat dari kurangnya skill atau keterampilan yang dimiliki. Padahal, usia mereka dalam masa produktif yaitu berada pada rentang umur 25 40 tahun.

Penyelsaian Permasalahan Desa marannu melalui Sosialisasi Pertanian (penggunaan pupuk organik dan bahaya penggunaan pupuk kimia), Sosialisasi Peternakan: (pemenuhan gisi ternak dan pemberian vaksin ternak), Pengolahan limbah pertanian menjadi pakan ternak dengan memanfaatkan teknologi pencacah limbah, Pengolahan limbah peternakan menjadi pupuk organik dengan memanfaatkan teknologi pencacah bahan baku pupuk dan Pemberdayaan masyarakat pengangguran dalam pengolahan pupuk organik dan pakan ternak.

Sosialisasi dilakukan dengan bekerjasama dengan penyuluh pertanian Kab. Pinrang dan kepala Desa Marannu. Sosialisasi dilakukan dengan memberikan pengetahuan kepada masyarakat tentang bahaya penggunaan pupuk anorganik (Pestisida) dan keuntungan dari femanfaatan limbah pertanian dan peternakan dalam memperbaiki kondisi lahan pertanian. Pertanian dan peternaka terintegrasi Desa Marannu mengangkat tema zero waste, dalam mengurai limbah menjadi pupuk organik. 


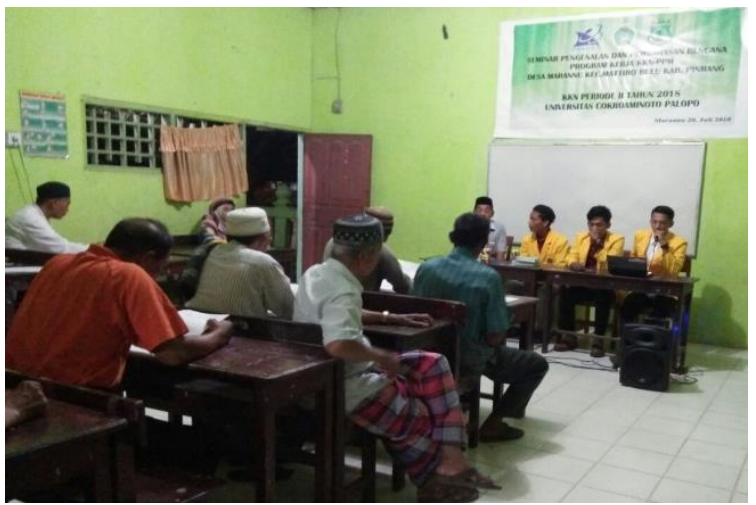

Gambar 1. Sosialisasi KKN PPM Desa Marannu

Demonstrasi pupuk organik dilakukan bersama masyrakat desa marannu seperti Kepala Desa, Kelompok Tani padi, ibu-ibu PKK, peternak ayam, peternak sapi dan ibu rumah tangga. Demonstrasi yang dilakukan yaitu pembuatan pupuk bokasi, POC, dan Vertikultur.

Pembuatan Pupuk bokasi dilakukan dengan memanfaatkan limbah peternakan dan pertanian. Limbah peternakan yang digunakan yaitu kotoran ayam dan urine sapi sedangkan limbah pertanian yaitu sekam dan jerami. Dalam proses pembuatan pupuk bokashi, bahan lain yang digunakan seperti teknologi EM-4 (Mikroorganisme Efektif) dan gula merah.

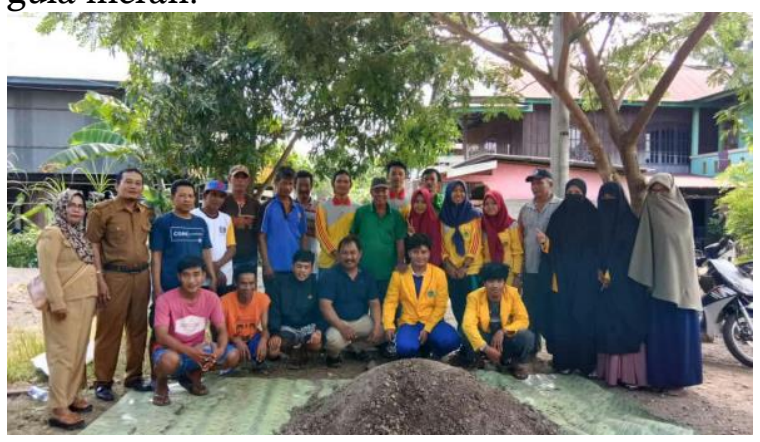

Gambar 2. Pelatihan Pembuatan Pupuk Organik

Setelah Demonstrasi Pembuatan Pupuk organik dilanjutkan dengan pembuatan POC (Pupuk Organik Cair). POC adalah larutan dari pembusukan bahan-bahan organic yang berasal dari sisa tanaman, kotoran hewan, dan manusia yang kandungan unsure haranya lebih dari satu unsure.

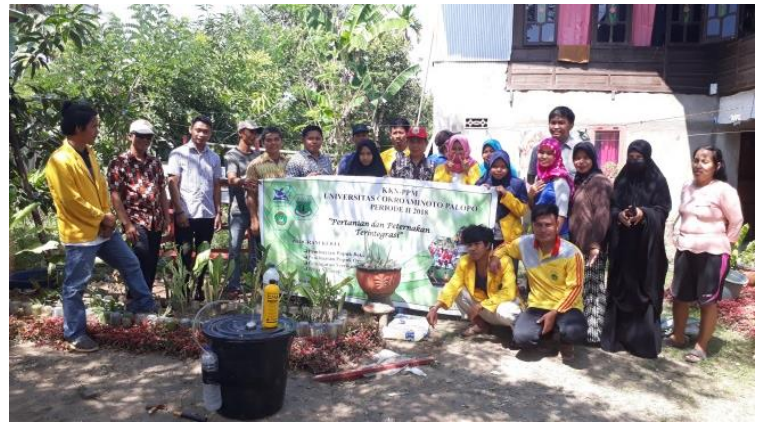

Gambar 3 Pelatihan Pembuatan Pupuk Organik Cair (POC)

Manfaat POC antara lain meningkatkan kesuburan tanaman, memperbaiki dan meningkatkan kualitas kandungan organik di dalam tanah, sehingga tanah atau lahan pertanian menjadi lebih remah, gembur dan tidak liat bahkan keras, menjaga ketersediaan unsur hara di dalam tanah, mengurangi polusi dan dampak sampah di lingkungan

Bentuk implementasi dari pupuk bokasi dan POC yang telah dibuat adalah melalui Vertikultur. Vertikultur merupakan Teknik dalam bertanam, yang dilakukan dengan menempatkan media tanam dalam suatu wadah-wadah yang disusun vertical. Vertikultur biasanya dimanfaatkan oleh orang-orang yang memiliki pekarangan rumah yang cukup lega untuk dimanfaatkan untuk berbudidaya tanaman.

Perbedaannya dengan system tanam konvensional adalah, jika dalam system tanam konvensional kita dapat langsung menanam tanaman di lahan tanah, namun pada system vertikultur kita menggunakan media tanam untuk melakukan penanaman.

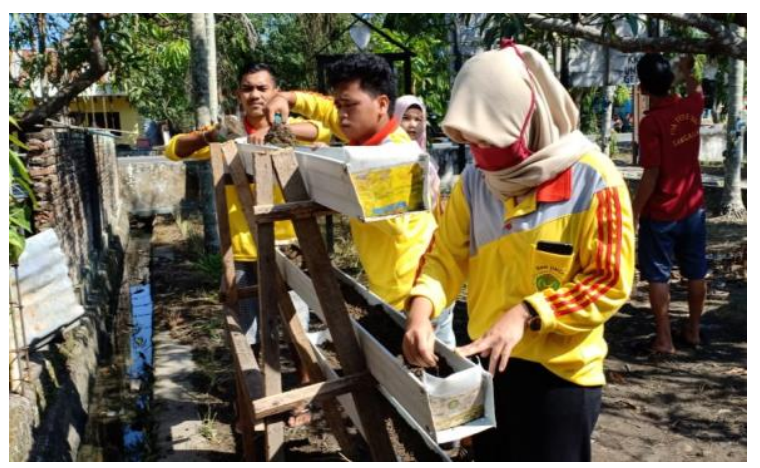

Gambar 4. Implementasi Pupuk Organik Melalui Vertikultur 
Caradde: Jurnal Pengabdian Kepada Masyarakat

Vol 1 No 2, Februari 2019

\section{SIMPULAN DAN SARAN}

Kegiatan KKN PPM Desa Marannu sebagai upaya pemanfaatan limbah pertanian dan peternakan dilakukan melalui (1) Sosialisasi Pertanian: Penggunaan pupuk organik dan bahaya penggunaan pupuk kimia, (2) Pengolahan limbah pertanian menjadi pakan ternak, (4) Pengolahan limbah peternakan menjadi pupuk organik, (5) Pemberdayaan masyarakat pengangguran dalam pengolahan pupuk organik dan pakan ternak. Sebagai luaran dalam kegiatan ini adalah (1) Peningkatan pengetahuan masyarakat desa marannu tentang petani tentang pembuatan pupuk oganik, (2) Modul Pembuatan Pupuk Bokasi dan POC dengan memanfaatkan limbah pertanian dan peternakan. (3) Peningkatan pengetahuan masyarakat desa marannu tentang Pemanfaatan alat pembakaran sekam dan (4) Peningkatan partisipasi masyarakat pengangguran melalui pengolahan dan pembuatan pupuk organik..

Melalui KKN PPM Desa marannu, kepala pemerintah setempat khusus kepala desa dan kecamatan Mattiro Bulu agar menjadikan pengolahan limbah pertanian dan pertanakan menjadi pupuk organik sebagai unit usaha desa. Sehingga nantinya desa Marannu menjadi Desa mandiri melalui peningkatan pendapatan petani dan penghasilan tambahan bagi desa

\section{DAFTAR RUJUKAN}

Badan Pusat Statistik (BPS). 2016. Pinrang dalam Angka. BPS Kab. Pinrang.

Das, A. 2013. Integrated Farming: An approach to boost up family farming. LEISA India Vol 15 .http://www.agriculturesnetwork.or g Diakses [17 November 2018].

Direktorat Jenderal Peternakan, (2010). Jakarta: Dirjen Pemderdayaan Sosial Departemen Sosial RI.
Direktorat Pemberdayaan Keluarga. (2007). Panduan Pendamping Pemberdayaan Perempuan No. 10/PS/PK/CTK/III/2007. Jakarta: Dirjen Pemderdayaan Sosial Departemen Sosial RI.

[FAO] Food and Agricultural Organization. 2015. Capture Fisheries and Aquaculture Production. http://www.fao.org/publications/st atistics/agricultural/ (Online). Diakses 29 Mei. 2016.

Handaka, dkk. 2009. Sistem integrasi ternaktanaman berbasis sawit, padi dan kakao. Bogor. Pusat Penelitian dan Pengembangan Peternakan

Haryanto B. dkk. 2002. Panduan Teknis Sistem Integrasi Padi Ternak. Jakarta; Departemen Pertanian

Lesmana, D. dkk, 2017. Tingkat Pengetahuan Petani Padi Sawah (Oryza sativa L.) Terhadap Pertanian Organik di Desa Manunggal Jaya Kecamatan Tenggarong.

Murbandono. (2008). Membuat Kompos. Penebar Swadaya: Jakarta.

Siswati, L. dkk. 2012 Model Pertanian Terpadu Tanaman Hortikultura dan Ternak Sapi untuk Meningkatkan Pendapatan Petani. Padang: Jurnal Peternakan Indonesia.

Sugeng, Y.B. 2013. Beternak Sapi Potong. Penebar Swadaya: Jakarta

Rusfidra. 2007. Paradigma Baru Pembangunan Peternakan; Membangunan Peternakan Bertumpu pada Ternak Lokal. Bogor: Cendekia Publishing House. 